\title{
BUILDING INTERNATIONAL APPROACHES TO CLIMATE CHANGE, DISASTERS, AND DISPLACEMENT
}

\author{
Jane McAdam*
}

On average, one person is displaced each second by a disaster-related hazard. Most people move within their own countries, but some are forced across international borders. This article outlines the scope of existing international legal frameworks to assist people displaced in the context of disasters and climate change, and suggests a variety of different tools that are required to address the phenomenon. Legal, policy, technical and scientific interventions, including disaster risk reduction, climate change adaptation and mitigation, development, and migration opportunities, will determine whether, and for how long, people can remain in their homes, and whether doing so enables them to lead dignified lives or exposes them to risks and increased vulnerability. Identifying the need for a broad, complementary set of policy strategies necessarily affects how international law should be progressively developed in this area.

En moyenne, une personne est déplacée à chaque seconde en raison d'un danger lié à une catastrophe. La plupart d'entre elles sont déplacées à l'intérieur de leur pays mais certaines sont obligées de se rendre à l'étranger. Dans cet article, l'auteure décrit dans les grandes lignes la portée des cadres juridiques internationaux existants qui aident les personnes déplacées en raison de catastrophes, climatiques notamment, et propose différents outils qui sont nécessaires pour répondre à ce phénomène. Les interventions juridiques, politiques, techniques et scientifiques, notamment la réduction des risques de catastrophe, les mesures d'adaptation aux changements climatiques et d'atténuation, le développement et les possibilités migratoires, déterminent si les gens peuvent rester chez eux et pendant combien de temps et si le fait de rester chez eux leur permet de vivre dans la dignité ou les expose à des dangers et accroît leur vulnérabilité. L'établissement de la nécessité de stratégies d'action vastes et complémentaires a forcément un effet sur le sens dans lequel on devrait faire évoluer progressivement le droit international dans ce domaine.

\section{INTRODUCTION}

On average, one person is displaced each second by a disaster-related hazard. In global terms, that is about twenty-six million people a year. ${ }^{1}$ In 2013 , almost three times as many people were newly

Scientia Professor and Director of the Andrew \& Renata Kaldor Centre for International Refugee Law, Faculty of Law, UNSW, Sydney, Australia. This research has been funded by an Australian Research Council Future Fellowship (FT110100721) and the Research Council of Norway (Project no 235638). This is the text of Jane McAdam's Access to Justice Distinguished Lecture presented at the Faculty of Law, University of Windsor on 18 October 2016. 
displaced by disasters than by conflict - around twenty-two million people. ${ }^{2}$ Most move within their own countries, but some are forced across international borders. In the aftermath of Cyclone Pam in the South Pacific in 2015, it was estimated that up to 70 percent of Vanuatu's population was displaced ${ }^{3}$ and 45 percent of Tuvalu's. ${ }^{4}$ Most of this was temporary, all of it was internal, but it is likely to happen more and more often as cyclones and similar extreme weather events become increasingly frequent and/or intense. There is now less sea ice in the Arctic Ocean than ever before and, in Alaska, the permafrost is melting. This is resulting in rapid erosion and flooding, threatening the livelihoods and well-being of those who reside there. It is jeopardizing the ongoing habitability of the land and prompting Native communities to request permanent relocation. ${ }^{5}$

In international law, only a small category of forced migrants are recognized as people whom other countries have an obligation to protect: "refugees," "stateless persons," and those eligible for complementary protection. In this article, I will outline the scope of existing international legal frameworks to assist people displaced in the context of disasters and climate change, before suggesting a variety of complementary tools that are needed to address this phenomenon. Legal, policy, technical, and scientific interventions, including disaster risk reduction, climate change adaptation and mitigation, development, and migration opportunities, will determine whether, and for how long, people can remain in their homes, and whether doing so enables them to lead dignified lives or exposes them to risks and increased vulnerability. Identifying the need for a broad, complementary set of policy strategies necessarily affects how international law should be progressively developed in this area.

\section{BACKGROUND}

There are a couple of preliminary matters we need to bear in mind when we think about designing strategies to address climate change, disasters, and human movement. The first is that I am going to refer both to climate change and to disasters. The reason for this is twofold. First, many disasters are

1 "Between 2008 and 2014 a total of 184.4 million people were displaced by sudden-onset disasters, an average of 26.4 million people newly displaced each year. Of these, an annual average of 22.5 million people was displaced by weatherand climate-related hazards. Others have to move because of the effects of sea level rise, desertification or environmental degradation." Nansen Initiative on Disaster-Induced Cross-Border Displacement (Nansen Initiative), "Agenda for the Protection of Cross-Border Displaced Persons in the Context of Disasters and Climate Change" (December 2015) at 6, online: <https://nanseninitiative.org/wp-content/uploads/2015/02/PROTECTION-AGENDA-VOLUME-1.pdf>; Internal Displacement Monitoring Centre (IDMC), "Global Estimates 2015: People Displaced by Disasters" (2015) at 8, online: $<$ http://www.internal-displacement.org/assets/library/Media/201507-globalEstimates-2015/20150713-global-estimates2015-en-v1.pdf>.

2 IDMC, "Global Estimates 2014: People Displaced by Disasters" (2014) at 7, 9.

3 Matthew Dornan, "Vanuatu after Cyclone Pam: The Economic Impact," Dev Policy Blog (10 April 2015), online: $<$ http://devpolicy.org/vanuatu-after-cyclone-pam-the-economic-impact-20150410/>; "70 Percent of Vanuatu's Population Displaced: Official," Pacific Islands News Association (16 March 2015), online: $<$ http://www.pina.com.fj/?p=pacnews\&m=read\&o=20970140535507a1fd8c02ba24b812>.

4 “45 Percent of Tuvalu Population Displaced: PM," Radio New Zealand (15 March 2015), online: $<$ http://www.radionz.co.nz/international/pacific-news/268686/45-percent-of-tuvalu-population-displaced-pm>.

5 See, e.g., Robin Bronen, "Climate-Induced Displacement of Alaska Native Communities," Brief, Brookings-LSE Project on Internal Displacement (30 January 2013), online: $<$ https://www.brookings.edu/wp-content/uploads/2016/06/30climate-alaska-bronen-paper.pdf $>$. 
exacerbated by climate change (such as increased cyclone intensity), while others (earthquakes and tsunamis) are generally not. Nevertheless, their impacts can be just as devastating, and, when it comes to human rights and protection needs, it makes little sense to distinguish between the two. Second, even if a climate sceptic disputes the connection between climate change and particular types of disasters, the reality is that the risk of disaster-related displacement has quadrupled since the 1970s. ${ }^{6}$ Irrespective of the underlying cause, how are we going to respond to the considerable legal and policy challenges this brings?

The second preliminary matter is this: we are discussing a multi-causal phenomenon. The impacts of climate change or disasters do not cause displacement on their own but, rather, interact with other economic, social, and political drivers that themselves affect migration - like impoverishment, environmental degradation, resource scarcity, lack of livelihood opportunities, and so on. This is true whether we consider the small-island developing state of Kiribati or the much larger country of Bangladesh.

Third, climate change functions as a threat amplifier, magnifying risk. Disasters become disasters on steroids: more frequent and more intense. Climate change is also a process. Slow-onset impacts such as sea level rise or desertification take place over time, resulting in a gradual deterioration of living conditions that ultimately renders land uninhabitable. These may pose a more permanent risk to the sustainability of certain human settlements over the long term.

Fourth, there is also a constant "dialogue" between the slower climate processes and more rapid-onset events. Slow-onset processes, like sea level rise and erosion, may exacerbate sudden-onset disasters, such as storm surges, king tides, and flooding. ${ }^{7}$ Cumulatively, these can weaken people's resilience over time and contribute to further displacement. ${ }^{8}$ For instance, history shows the resourcefulness and resilience of many communities in the face of adversity - from small Pacific islands to the Arctic - but traditional coping mechanisms are now being challenged by the recurrence and intensity of extreme weather events.

Finally, each community will experience the adverse impacts of climate change and disasters differently, and, even within communities, different individuals will have different "tipping points." In fact, what transforms a "hazard" into a "disaster" is that people's coping capacity is exceeded. This means that there is really no such thing as a "natural" disaster - disasters are always contingent on underlying social, economic, political, and environmental factors. This is why good governance is so crucial. The nature and timing of policy interventions will play a major role in determining the outcomes following a disaster, since they affect people's resilience and coping capacity. They can influence whether people move at all, whether they are displaced for prolonged periods, what resources they can access and how readily, and whether they have options to move to more secure areas to rebuild their lives. For instance, if building codes are implemented and enforced, then people will be safer. If

6 Justin Ginetti, Disaster-Related Displacement Risk: Measuring the Risk and Addressing Its Drivers (Geneva: IDMC, 2015) at 8.

7 Climate Council, "Damage from Cyclone Pam Was Exacerbated by Climate Change," Briefing Statement (2015) at 3 , online: <http://www.climatecouncil.org.au/uploads/417d45f46cc04249d55d59be3da6281c.pdf $>$.

8 Jane McAdam et al, "International Law and Sea-Level Rise: Forced Migration and Human Rights," Fridtjof

Nansen Institute \& Andrew \& Renata Kaldor Centre for International Refugee Law FNI Report 1/2016 (2016) at para 53, online: <http://www.kaldorcentre.unsw.edu.au/sites/default/files/FNI-R0116.pdf>. 
disaster-warning systems are in place, then people will have time to get themselves out of harm's way. Evidence shows that most people want to remain in their homes for as long as they can and return as quickly as possible. But if people cannot live in safety, dignity, and with access to livelihoods, then they may seek to move on.

\section{WHAT IS THE ROLE OF THE LAW IN ALL OF THIS?}

Under international human rights law, states have the primary responsibility to promote and protect the human rights of all people within their territory or jurisdiction - both citizens and non-citizens. Where people are displaced within national borders, states' obligations are clear and are further clarified by relevant soft law instruments such as the Guiding Principles on Internal Displacement (Guiding Principles). ${ }^{9}$ The Guiding Principles, adopted in 1998, are recognized by the international community as an "important international framework for the protection of internally displaced persons," addressing people's needs and rights before, during, and after displacement. ${ }^{10}$ The challenge lies in strengthening their normative and operational implementation in the context of climate change and disasters and in enhancing the capacity of the relevant authorities to apply them. ${ }^{11}$

When it comes to cross-border movement, current legal protection frameworks do not provide a means for people to move in anticipation of future environmental harm, even though it is entirely rational for people to calculate the future risks and decide that they would rather leave now than stay and wait for the situation to become intolerable. International refugee law will generally not assist. Under the Convention Relating to the Status of Refugees (Refugee Convention), a person only qualifies as a refugee if they have a well-founded fear of persecution for reasons of race, religion, nationality, political opinion, or membership of a particular social group and cannot obtain the protection of their country. ${ }^{12}$ In general, the impacts of climate change or disasters will not satisfy these criteria. First, there will be difficulties in showing that these impacts amount to "persecution," as that term is currently understood in law. While adverse climate impacts such as rising sea levels and increases in the frequency and/or severity of cyclones, floods, and so on are harmful, they do not meet the threshold of "persecution," which normally requires human agency. Indeed, if anything, the "persecutor" here is industrialized states, whose failure to reduce their carbon emissions has contributed to the predicament now being faced - the very countries to which movement might be sought if the land becomes unsustainable, which is a complete reversal of the traditional refugee paradigm. ${ }^{13}$ The New Zealand Court of Appeal described this as an attempt "to stand the Convention on its head.","

9 Guiding Principles on Internal Displacement, UN Doc E/CN.4/1998/53/Add.2 (1998).

10 UNGA, "World Summit Outcome," UN Doc A/RES/60/1 (24 October 2005) at para 132.

11 McAdam et al, supra note 8 at para 76; International Law Association (ILA), "International Law and Sea Level Rise: Interim Report" (8 June 2016) at 25.

12 Convention Relating to the Status of Refugees, 28 July 1951, 189 UNTS 137, art 1A(2), read in conjunction with the Protocol Relating to the Status of Refugees, 31 January 1967, 606 UNTS 267.

13 Jane McAdam, Climate Change, Forced Migration, and International Law (Oxford: Oxford University Press, 2012) at 45.

14 Teitiota $v$ Chief Executive of the Ministry of Business, Innovation and Employment, [2014] NZCA 173 at para 40 [Teitiota 2014]. 
Even if it were possible to overcome this hurdle, the further requirement under the Refugee Convention, that persecution be for reasons of an individual's race, religion, nationality, political opinion, or membership of a particular social group, poses an additional obstacle. The impacts of climate change and natural disasters are largely indiscriminate, and someone fleeing the indiscriminate effects of a natural disaster would not be eligible for protection because of the absence of a link to a Refugee Convention ground. ${ }^{15}$ Courts around the world have held that the Refugee Convention does not generally protect victims of natural disasters or those in search of better living conditions, even though "both of these cases might seem deserving of international sanctuary." 16

Between 2000 and 2015, there were over twenty cases in Australia and New Zealand where people from Tuvalu and Kiribati argued that they should receive refugee protection from climate change impacts, but all failed. ${ }^{17}$ The decision makers explained that the applicants were not "differentially at risk of harm amounting to persecution due to any one of these five grounds", that "all citizens face[d] the same environmental problems and economic difficulties" and that they were the "unfortunate victims ... of the forces of nature." ${ }^{18}$ New Zealand case law is the most developed in this field. It has recognized that there may be limited cases where existing refugee law could apply. An example would be if a government restricted access to fresh water supplies or to humanitarian assistance in the aftermath of a disaster, for a Convention reason, and as a consequence exposed people to treatment amounting to persecution. ${ }^{19}$ However, it would be the act or omission by the government that constituted the harm, rather than the disaster or resource scarcity itself. The latter would merely provide the context for the conventional refugee claim.

In my view, human rights law provides the most scope for protecting people against forcible return to circumstances where they face arbitrary deprivation of life, or cruel, inhuman, or degrading treatment. It is possible that conditions in a disaster-affected area, or an area rendered uninhabitable by the impacts of climate change, may mean that returning someone there would expose them to a real risk of death or

15 AF (Kiribati), [2013] NZIPT 800413 at para 56 [AF (Kiribati) 2013]; Teitiota v Chief Executive of the Ministry of Business Innovation and Employment, [2013] NZHC 3125 at para 54 [Teitiota 2013]; Teitiota 2014, supra note 14 at para 19.

16 Canada (Attorney General) v Ward, [1993] 2 SCR 689 at 732; Applicant A v Minister for Immigration and Ethnic Affairs, (1997) 190 CLR 225 at 248 (Dawson J); Horvath v Secretary of State for the Home Department, [2001] 1 AC 489 at 499-500 (Lord Hope); Minister for Immigration v Haji Ibrahim, (2000) 204 CLR 1 at 48-49 (Gummow J).

17 AF (Tuvalu), [2015] NZIPT 800859; AD (Tuvalu), [2014] NZIPT 501370; AC (Tuvalu), [2014] NZIPT 800517-520 [AC (Tuvalu)]; Teitiota 2013, supra note 15; Teitiota 2014, supra note 14; AF (Kiribati) 2013, supra note 15; Refugee Appeal no 72719/2001, RSAA (17 September 2001) (Tuvalu); Refugee Appeal no 72313/2000, RSAA (19 October 2000) (Tuvalu); Refugee Appeal no 72314/2000, RSAA (19 October 2000) (Tuvalu); Refugee Appeal no 72315/2000, RSAA (19 October 2000) (Tuvalu); Refugee Appeal no 72316/2000, RSAA (19 October 2000) (Tuvalu); Refugee Appeal nos 72179-72181/2000, RSAA (31 August 2000) (Tuvalu); Refugee Appeal nos 72189-72195/2000, RSAA (17 August 2000) (Tuvalu); Refugee Appeal no 72185/2000, RSAA (10 August 2000) (Tuvalu); Refugee Appeal no 72186/2000, RSAA (10 August 2000) (Tuvalu). Australian cases: 1004726, [2010] RRTA 845 (30 September 2010) (Tonga); 0907346, [2009] RRTA 1168 (10 December 2009) (Kiribati); N00/34089, [2000] RRTA 1052 (17 November 2000) (Tuvalu); N95/09386, [1996] RRTA 3191 (7 November 1996) (Tuvalu); N96/10806, [1996] RRTA 3195 (7 November 1996) (Tuvalu); N99/30231, [2000] RRTA 17 (10 January 2000) (Tuvalu); V94/02840, [1995] RRTA 2383 (23 October 1995) (Tuvalu).

18 Refugee Appeal no 72189/2000, NZ Refugee Status Appeals Authority (17 August 2000) at para 13.

19 AF (Kiribati) 2013, supra note 15 at paras 58-59. 
cruel, inhuman, or degrading treatment. This is especially so when the conditions are considered cumulatively (for example, if the area is disaster prone, there are extreme water shortages, crops can no longer grow, or there is a heightened risk of illness). Courts have recognized that "destitution" or "dire humanitarian conditions" can amount to inhuman or degrading treatment, especially cumulatively. The advantage of this approach is that, by focusing on the underlying human rights that are compromised, it avoids complex issues of causation about climate change that are not directly relevant to establishing whether or not a right has been violated.

New Zealand decision makers have accepted that disasters, including those linked to climate change, could in principle "provide a context in which a claim for recognition as a protected person" might be grounded. ${ }^{20}$ This is because states have an obligation to respect, protect, and fulfil human rights to protect people from foreseeable harm. ${ }^{21}$ However, placing a strong emphasis on the role of the home government, New Zealand's jurisprudence has essentially held that if a government is taking steps within its power to protect people from the effects of climate change, then it will not abrogate its obligations under human rights law. Since a government would be faced with "an impossible burden" were it required as a matter of law to mitigate all environmental hazards, an assessment of its positive obligations to protect life must be "shaped by this reality.",2 This draws on similar jurisprudence by the European Court of Human Rights, which seems to accept a lower threshold when it comes to natural, versus man-made, hazards. $^{23}$

Further, courts and legislatures have carefully confined the meaning of "inhuman or degrading treatment" so that it cannot be a catch-all for general poverty, unemployment, or a lack of resources or medical care except in exceptional circumstances. ${ }^{24}$ Again, they have shown great reluctance in finding that a person needs international protection unless the government has deliberately withheld resources from them or actively occasioned harm. ${ }^{25}$ This is why Australian law requires that inhuman or degrading treatment be "intentionally inflicted," for instance. ${ }^{26}$ In addition, it would seem that harm must be relatively imminent before international protection would be regarded as an appropriate solution, which may be problematic for creeping slow-onset processes. ${ }^{27}$ Although New Zealand jurisprudence requires only that there is "sufficient evidence to establish substantial grounds for believing the appellant would

20 AC (Tuvalu), supra note 17 at para 70.

21 "Human Rights and Climate Change," UN Doc A/HRC/26/L.33/Rev.1 (25 June 2014) at para 1. Other resolutions on this subject include UN Doc A/HRC/RES/7/23 (28 March 2008); UN Doc A/HRC/RES/10/04 (25 March 2009); UN Doc A/HRC/RES/18/22 (17 October 2011); UN Doc A/HRC/29/L.21 (30 June 2015).

22 AC (Tuvalu), supra note 17 at para 75.

23 ECtHR, Budayeva v Russia, Appl nos 15339/02, 21166/02, 20058/02, 11673/02, and 15343/02 (20 March 2008); ECtHR, Öneryildiz v Turkey, Appl nos 48939/99 (30 November 2004).

24 ECtHR, D v United Kingdom, Appl 30240/96 (21 April 1994); N v Secretary of State for the Home Department, [2005] UKHL 31; ECtHR, HLR v France, Appl no 24573/94 (22 April 1997) at para 42; see also the views of the Committee against Torture, as in $A D v$ The Netherlands, Communication no 96/1997, UN Doc CAT/C/23/D/96/1997 (24 January 2000) at para 7.2 .

25 See, e.g., $B G$ (Fiji), [2012] NZIPT 800091 at para 148: "Treatment" requires a positive act or omission by an authority that "transcend[s] failure of the state's general economic policies to provide for an adequate standard of living."

26 Migration Act (Cth), s 5(1): definitions of "cruel or inhuman treatment or punishment," "degrading treatment or punishment."

27 See McAdam, supra note 13 at 84-87. 
be in danger," 28 similar to the "well-founded fear" test in refugee law, a risk to life from sea-level rise and natural disasters has been found, in the cases heard to date, to fall "well short of the threshold required to establish substantial grounds for believing that they would be in danger of arbitrary deprivation of life" and "remains firmly in the realm of conjecture or surmise.",29

In 2005, the Inuit peoples of the Arctic regions of the United States and Canada lodged a petition with the Inter-American Commission on Human Rights, asserting that the United States' failure to ratify the Kyoto Protocol and reduce its greenhouse gas emissions violated certain fundamental rights, including the right to life, health, physical integrity, a means of subsistence, property, and inviolability of the home. ${ }^{30}$ Although the petition was ultimately dismissed, and evidence was instead presented by way of a general hearing on human rights issues rather than as contentious litigation, the case raised important questions about whether a state's failure to ratify key international instruments aiming to combat climate change could, inter alia, constitute a breach of human rights law, the principle of good faith in upholding international obligations, and the duty to cooperate in international environmental law.

There is no doubt that strategic litigation, such as in New Zealand and the Inter-American Commission on Human Rights, has played an important role in drawing attention to legal gaps and grey areas. It is fortunate that the tribunal member who heard the New Zealand cases was someone with specialist expertise in climate change and displacement and was alert to the nuanced legal and empirical challenges that it presents. There is always a risk in any strategic litigation, though, that if a test case is not solid, or a decision maker is not sufficiently across the issues, then an unfortunate precedent might result that is difficult to undo. On the other hand, even if the courts never find that existing law has the capacity to provide protection, this might itself help to catalyze action, creating the necessary impetus and political will to help drive other policy changes. ${ }^{31}$

Before I turn to what some of those other changes might be, I want to mention the statelessness regime. There is a widespread misconception that if low-lying small island states are rendered uninhabitable by sea level rise, their people will become stateless. However, it is important to appreciate that well before the land mass is submerged, other factors will make it unsuitable for human habitation. One of the main problems is likely to be saltwater intrusion, corrupting fresh water supplies and jeopardizing agricultural land, which, in turn, will affect livelihoods and food security. This means that people will need to move before the land itself is inundated. Prolonged drought in the Pacific islands of Tuvalu and Tokelau led their governments to declare a state of emergency in 2011 because of severe

28 AF (Kiribati) 2013, supra note 15 at para 90.

29 Ibid at para 91. There was insufficient evidence to show that the conditions on return would be "so parlous that [the applicants'] life [would] be placed in jeopardy, or that [they would] not be able to resume their prior subsistence life with dignity" (at para 74).

30 "Petition to the Inter American Commission on Human Rights Seeking Relief from Violations resulting from Global Warming caused by Acts and Omissions of the United States" (7 December 2005), online:

$<$ http://www.ciel.org/Publications/ICC_Petition_7Dec05.pdf>. Kyoto Protocol, 1998, 37 ILM 22 (1998).

31 "Political will in relation to climate change has not been strong and much litigation concerning climate change has been about catalyzing action." Elizabeth Fisher, Eloise Scotford \& Emily Barritt, "Why Understanding the Legally Disruptive Nature of Climate Change Matters" (22 April 2015), online: <http://blog.oup.com/2015/04/legally-disruptive-nature-ofclimate-change/\#sthash.mRtXuuGq.dpuf $>$. 
water shortages. Australia and New Zealand responded quickly by sending emergency desalination plants, rehydration packs, technical support, and water supplies, but quite clearly this is not a sustainable long-term response.

From a legal perspective, the law on statelessness is ill-fitting. The legal definition of a "stateless" person in article 1(1) of the Convention Relating to the Status of Stateless Persons is deliberately very narrow: someone who is "not considered as a national by any State under the operation of its law." The concept does not even extend to de facto statelessness - that is, where someone has a nationality but is unable to exercise the rights of a citizen. The "statelessness" definition would therefore not apply to someone whose country is at risk of inundation, unless the country were to formally withdraw nationality from them (which would violate international law). ${ }^{32}$ Some scholars have pondered whether it might apply if the state itself no longer existed, since then there would be no "state" to provide nationality.

International legal principles on the extinction of states do not contemplate the physical disappearance of states. To examine this question, scholars have tried to reverse engineer the creation of states. For a "state" to exist, it must have a defined territory, a permanent population, an effective government, and the capacity to enter into relations with other countries. ${ }^{33}$ Yet, while all elements must be present for a state to come into existence, the absence of one or more does not necessarily mean the end of a state. Without going into the technical details here, history shows that the international community tends to presume the continuity of existing countries, even when some of the formal criteria of statehood (territory, population, governance) start to wane. ${ }^{34}$ As Walter Kälin has observed, it is "difficult to imagine that any other UN member state would want to tarnish its own reputation by being seen as lacking any compassion for the dire fate of such island states by asking for their exclusion from ... international organisations." 35 Presumably, then, the "deterritorialized" state would continue to interact as part of the community of nations. In any case, the statelessness treaties are poorly ratified, and few states have a procedure for identifying stateless people in their territory. ${ }^{36}$ Accordingly, there are no clear means by which the regime's benefits could be accessed in this context.

32 See Convention on the Reduction of Statelessness, 30 August 1961, 989 UNTS 175, art 8; International Covenant on Civil and Political Rights, 16 December 1966, 999 UNTS 171, art 24(3); Universal Declaration of Human Rights, 10 December 1948, UNGA Res 217A (III), art 15; Convention Relating to the Status of Stateless Persons, 28 September 1954, 360 UNTS 117, art 32.

33 Montevideo Convention on the Rights and Duties of States, 26 December 1933, 165 LNTS 19, art 1, which is now generally accepted as reflecting the position in customary international law.

34 See generally McAdam, supra note 13 at 119-60; Rosemary Rayfuse, "International Law and Disappearing States: Maritime Zones and the Criteria for Statehood" (2011) 41 Envtl Pol'y \& L 281; Derek Wong, "Sovereignty Sunk? The Position of 'Sinking States' at International Law" (2013) 14 Melbourne J Intl L 346; Jenny Grote Stoutenburg, "When Do States Disappear?: Thresholds of Effective Statehood and the Continued Recognition of 'Deterritorialized' Island States" 57 and Maxine A Burkett, "The Nation Ex-Situ” 89, both in Michael B Gerrard \& Gregory E Wannier, eds, Threatened Island Nations: Legal Implications of Rising Seas and A Changing Climate (New York: Cambridge University Press, 2013).

35 Walter Kälin, "Conceptualising Climate-Induced Displacement" in Jane McAdam, ed, Climate Change and Displacement: Multidisciplinary Perspectives (Oxford: Hart Publishing, 2010) 102.

36 See Michelle Foster, Jane McAdam \& Davina Wadley, "The Protection of Stateless Persons in Australian Law: The Rationale for a Statelessness Determination Procedure” (2016) 40 Melbourne U L Rev [forthcoming]. 


\section{RESPONSES}

There are certainly some protection gaps, but there is not a complete legal void. Perhaps unsurprisingly, some people's imagination has been captured by the "big" questions - the idea of "climate refugees" or "sinking island nations" - and the assumption that we need new international treaties to address them. States themselves are very reticent to develop new international standards at this time. But even among legal experts involved in thinking through these issues, there is a broad consensus that it is premature to push for a new standard-setting agreement at the global level. Aside from the lack of political will to develop a new normative framework, an over-emphasis on this could distract from the distinct need for - and more feasible prospects of - effective practices and legislative change at the local, national, bilateral, and regional levels, which together form part of a global effort. This does not rule out the progressive development of the law at the international level, but nor is it contingent on it.

There are other issues too. Why single out specific drivers of movement, when we know that they are multi-causal? Why "climate change" or "disasters", rather than "abject poverty"? Also, the Refugee Convention is one of the most widely ratified treaties in the world, yet we have more displaced people now than at any time since the Second World War. Treaties must be implemented to be effective, and that requires political will. ${ }^{37}$ Perhaps the key point here is that much more can be done at a level that does not require any new international law. As Liz Fisher, Eloise Scotford, and Emily Barritt have argued, "[t]he 'super wicked' characterization of climate change as a scientific problem has resulted in a determined focus on finding solutions," and "the international treaty process is seen as the ultimate panacea." ${ }^{38}$ While treaties are important, "equally important is to understand exactly what type of problem climate change is. Only with that understanding can long-lasting legal responses to climate change be developed. ${ }^{, 39}$ In the current context, what we need are laws and policies that permit people to remain in their homes where possible and desirable, to move elsewhere before disaster strikes, and to receive assistance and protection if they are displaced. ${ }^{40}$ Some simple measures that can help to avert displacement include ensuring that building codes are implemented and enforced, that land is not overused for unsustainable development, and that better planning laws are put in place. These kinds of legal responses might not be as racy as new treaties, but they can make a considerable difference on the ground.

\section{TOOLBOX}

How best to respond to this phenomenon was behind the creation of the Nansen Initiative on Disaster-Induced Cross-Border Displacement (Nansen Initiative) in October 2012, a three-year

37 For a detailed analysis, see Jane McAdam, "Swimming against the Tide: Why a Climate Change Displacement Treaty is Not the Answer" (2011) 23 Intl J of Refugee L 1.

38 Fisher, Scotford \& Barritt, supra note 38.

39 Ibid. See also Elizabeth Fisher, Eloise Scotford \& Emily Barritt, "The Legally Disruptive Nature of Climate Change" (2017) 80 MLR [forthcoming].

40 ILA, supra note 11 at 22. 
intergovernmental initiative, led by Norway and Switzerland. It adopted a consultative, bottom-up approach "to build consensus on the development of a protection agenda addressing the needs of people displaced across international borders by natural disasters, including the effects of climate change." ${ }^{41}$ Through a series of seven sub-regional consultations between 2013 and 2015, it created a more nuanced, empirically based understanding of these issues.

In October 2015, the Nansen Initiative presented the Agenda for the Protection of Cross-Border Displaced Persons in the context of Disasters and Climate Change, which was endorsed by 109 governments. It is not legally binding but sets out a "toolbox" of concrete measures and effective practices that governments can implement now to avoid displacement where possible, to create migration opportunities, and to protect and assist those who are displaced. First, states should enhance disaster risk reduction measures and climate change adaptation to build community resilience. ${ }^{42}$ Through the systematic integration of disaster risk reduction measures, people will have a better chance of avoiding displacement if disaster strikes or being displaced for a much shorter period. The Sendai Framework on Disaster Risk Reduction 2015-30 notes the importance of creating "public policies ... aimed at addressing the issues of prevention ... of human settlements in disaster risk zones" ${ }^{\text {"43 }}$ and calls for the promotion of "transboundary cooperation ... to build resilience and reduce disaster risk, including ... displacement risk." ${ }^{44}$

Second, providing timely support and assistance is also key. We know from studies of floods in Bangladesh that when people receive prompt and adequate assistance, they are more likely to stay and rebuild than to move on in search of work to survive. By contrast, a year after Typhoon Haiyan struck the Philippines, tens of thousands of people remained displaced because the authorities said it was unsafe for them to go home but could not offer them any alternative. That is the kind of situation that is likely to see people try to move on themselves in precarious circumstances.

Third, regardless of what mitigation or adaptation strategies are put in place, some displacement is inevitable. ${ }^{45}$ States should ensure that there are appropriate laws and policies in place to address the needs of internally displaced persons, who will comprise the vast majority of displaced people. ${ }^{46}$ They should also create more predictable humanitarian and temporary stay arrangements for people who cross a border, especially in regions where disaster-related displacement is common (for example, Central America). For instance, a number of states already enable temporary stay for foreigners caught abroad when a disaster occurs back in their home country (for example, temporary protected status in the United States). In recent years, at least fifty states have "received or refrained from returning people in the aftermath of disasters, in particular those caused by tropical storms, flooding, drought, tsunamis, and

\footnotetext{
41 Nansen Initiative, "Towards a Protection Agenda for Disaster-Induced Cross-Border Displacement: Information Note" (20 October 2013) at 1, online:

$<$ http://www.nanseninitiative.org/sites/default/files/Nansen\%20Initiative\%20Information\%20Note\%2020.10.2013_0.pdf>.

42 See Protection Agenda, supra note 1 at paras 76-86, 117-118.

43 Sendai Framework for Disaster Risk Reduction 2015-2030, UN Doc A/RES/69/283 (23 June 2015) at para 27, online: $<$ http://www.preventionweb.net/files/resolutions/N1516716.pdf $>$ [Sendai Framework].

$44 \quad$ Ibid at para 28.

45 Government Office for Science, Foresight: Migration and Global Environmental Change; Future Challenges and Opportunities (London: Government Office for Science, 2011) at 9-10.

46 Protection Agenda, supra note 1 at paras 99-105, 123-124.
} 
earthquakes, ${ }^{, 47}$ but responses have been ad hoc and uncertain. More systematic and predicable responses need to be created.

Fourth, movement away from affected areas can itself be a form of adaptation. States should boost voluntary migration opportunities so that people may move in anticipation of future harm. ${ }^{48}$ Indeed, in this context, the Australian government has acknowledged that the promotion of "safe and well managed migration schemes" is "a key part of building resilience." particularly affected countries preferential access to existing migration categories (for example, skills, family, education), whether by prioritizing them or by waiving some of the usual requirements, establishing training programs in areas of need and thus giving people the skills they need to migrate for labour reasons, creating special visa categories for people living in particular regions, or establishing bilateral or regional free movement agreements. ${ }^{50}$ In the Pacific, more permanent migration might enable a smaller population to remain at home for longer, given that population pressure places strain on scarce resources. ${ }^{51}$

Already, targeted work and education schemes (for both temporary and permanent movement) permit small numbers of Pacific islanders to move to Australia and New Zealand annually. A good example is the innovative scheme that Australia ran with Kiribati between 2006 and 2014. ${ }^{52}$ It enabled almost ninety students from Kiribati to train as nurses at Griffith University in Australia. On graduation, they were eligible to apply for an eighteen-month temporary graduate visa (subclass 485), which increased their chances of subsequent employer sponsorship for a permanent visa. ${ }^{53}$ This program simultaneously responded to Kiribati's rapid population growth and youth unemployment rates, a nursing skills shortage in Australia (and globally), and provided a livelihood diversification strategy. If graduates returned home, they took valuable skills with them.

An ongoing program is New Zealand's Pacific Access Category, which provides permanent residence annually to 250 citizens from Fiji, 250 from Tonga, seventy-five from Tuvalu, and seventy-five from Kiribati. Eligibility depends on a person having an offer of ongoing and sustainable employment in New

$47 \quad$ Ibid at 6 (executive summary).

48 Ibid at paras 87-93, 119-120.

49 Nansen Initiative, "Global Consultation Conference Report: Geneva, 12-13 October 2015" (December 2015$)$ at 77 [Nansen Initiative]; see also 137 (statement by Kiribati).

50 See, e.g., Bruce Burson \& Richard Bedford, "Clusters and Hubs: Toward a Regional Architecture for Voluntary Adaptive Migration in the Pacific," Discussion Paper (9 December 2013), Executive Summary, online:

$<$ https://www2.nanseninitiative.org/wpcontent/uploads/2015/02/DP_Clusters_and_Hubs_Toward_a_Regional_Architect ure_for_Voluntary_Adaptive_Migration_in_the_Pacific.pdf $>$.

51 See McAdam, supra note 13 at 36; Richard Bedford \& Charlotte Bedford, "International Migration and Climate Change: A Post-Copenhagen Perspective on Options for Kiribati and Tuvalu” in Bruce Burson, ed, Climate Change and Migration: South Pacific Perspectives (Wellington: Institute of Policy Studies, 2010) 89.

52 Lea Shaw, Murray Edwards \& Akka Rimon, "Kiribati-Australia Nursing Initiative Independent Review: Review Report" (2014), online: <http://dfat.gov.au/about-us/publications/Documents/kiribati-australia-nursing-initiativeindependent-report.pdf $>$. See also Lara K O’Brien, “"Migrating with Dignity': A Study of the Kiribati-Australia Nursing Initiative (KANI)" (MA thesis, Department of Geography, University of Kansas, 2013), online: $<$ https://kuscholarworks.ku.edu/bitstream/handle/1808/12947/OBrien_ku_0099M_13103_DATA_1.pdf;sequence=1>.

53 An independent review of the program recommended that "[i]f KANI is to be re-designed as a labour migration program, support for the long-term and complex visa application process needs careful consideration." Shaw, Edwards \& Rimon, supra note 52 at 30. 
Zealand, a minimum level of English, a minimum income, and meeting health and character requirements. This scheme is well known in the Pacific and is generally regarded positively, although evidence shows that migrants often face significant financial pressures because of the considerable role they take on to support new arrivals from their community (increased weekly costs of 30 to 60 percent, in some cases). ${ }^{54}$ Finally, planned relocations can help people to move out of dangerous areas in advance or to resettle in safer areas after a disaster if return home is not possible. ${ }^{55}$ For the past fifty years or so, most planned relocations have occurred within countries in the context of development projects, and most have led to impoverishment and discontent.

Relocation is a complex and fraught process, requiring in-depth consultation and planning to avoid greater vulnerability. ${ }^{56}$ There is widespread recognition that relocation should only occur with the free and informed consent of the communities concerned. They must have accurate, up-to-date, and culturally relevant information in order to weigh the benefits and the risks involved. In the Pacific, the importance of engaging churches, traditional leaders, and civil society has been noted, for example. ${ }^{57}$ There have already been some internal relocations on account of disasters, ${ }^{58}$ and Fiji has begun implementing a specific internal relocation plan for villages affected by the impacts of climate change. ${ }^{59}$ In Alaska, the residents of Newtok have spearheaded a community-led initiative to relocate on account of melting permafrost and the loss of livelihoods. As a small community of only 360 people, a nuanced and individualized information-gathering process was possible, ${ }^{60}$ leading the Newtok Traditional Council to create a detailed relocation plan with both short-term and long-term objectives. ${ }^{61}$ In larger communities, all of the relevant agencies and community groups will need to be carefully identified so that relevant information can gathered and processed.

54 Deborah McLeod, "Potential Impacts of Climate Change Migration on Pacific Families Living in New Zealand" in Burson, supra note 51, 156.

55 Protection Agenda, supra note 1 at paras 94-98, 121-122.

56 Elizabeth Ferris, "Protection and Planned Relocations in the Context of Climate Change," UNHCR Legal and Protection Policy Research Series PPLA/2012/04 (August 2012); Alice R Thomas, "Post-Disaster Resettlement in the Philippines: A Risky Strategy" (2015) 49 Forced Migration Review 52; Jane McAdam \& Elizabeth Ferris, "Planned Relocations in the Context of Climate Change: Unpacking the Legal and Conceptual Issues" (2015) 4 Cambridge J Intl \& Comp L 137; see also "Guidance on Protecting People from Disasters and Environmental Change through Planned Relocation," Brookings, Georgetown University, and UN High Commissioner for Refugees (7 October 2015), online: $<$ http://www.brookings.edu/ /media/research/files/papers/2015/10/07-planned-relocation-guidance/guidance_plannedrelocation_14-oct-2015.pdf>.

57 Nansen Initiative, "Human Mobility, Natural Disasters and Climate Change in the Pacific: Outcome Report," Cook Islands (21-24 May 2013) at 27, online: <https://www.nanseninitiative.org/portfolio-item/pacific-outcome-report/>.

58 See, e.g., Thomas, supra note 56; Gemma Sou, "Post-Disaster Resettlement in Urban Bolivia" (2015) 49 Forced Migration Review 33.

59 Karen E McNamara \& Helene Jacot Des Combes, "Planning for Community Relocations due to Climate Change in Fiji" (2015) 6 International Journal of Disaster Risk Science 315.

60 See Arctic Slope Consulting Group, "Newtok: Background for Relocation Report," Newtok Traditional Council (January 2004) at 15-20, online: <http://commerce.alaska.gov/dnn/Portals/4/pub/NewtokBackgroundRelocation2004.pdf>; see also Appendix F (pros and cons of different relocation sites); Appendix I (relocation survey documentation, including details of the voting process and detailed results).

61 Robin Bronen, "Climate-Induced Community Relocations: Creating an Adaptive Governance Framework Based in Human Rights Doctrine” (2011) 35 NYU Rev Law \& Social Change 357, 388. 
While most relocations have taken place within countries, the 1940s saw a small number of crossborder relocations in the Pacific. ${ }^{62}$ The deep, inter-generational psychological consequences that remain seventy years on explain why today it is considered the "option of last resort." ${ }^{\text {"63 }}$ Cross-border relocation involves complex logistical considerations, as well as profound challenges and anxieties relating to identity, social coherence, and culture. There are also challenging legal dimensions relating to selfdetermination, citizenship, and social and cultural rights.

\section{CONCLUSION}

There are many effective practices that states could adopt now that would significantly reduce future displacement in the context of disasters or climate change. The choices that states make today will impact on whether people will be able to remain in their homes, whether they will be displaced for prolonged periods, whether they will have access to assistance (and how readily), and whether they will have options to return home safely or to move to more secure areas to rebuild their lives. Simple things like ensuring that building codes are implemented and enforced and that disaster-warning systems are in place can greatly enhance people's safety.

In July 2016, the Platform on Disaster Displacement was launched by the governments of Germany and Bangladesh. As the successor to the Nansen Initiative, it will continue its crucial work in consolidating and enhancing the use of effective practices and promoting policy coherence by linking with existing initiatives. As a state-led process, the Nansen Initiative played a major role in getting important language on human mobility incorporated into the Sendai Framework ${ }^{64}$ and into the 2015 outcome document of the Paris climate change conference.$^{65}$ One result of the Paris conference was the creation of a task force under the auspices of the Warsaw International Mechanism for Loss and Damage associated with Climate Change Impacts "to develop recommendations for integrated approaches to avert, minimize and address displacement related to the adverse impacts of climate change., ${ }^{, 96}$ This will help to create an action-oriented agenda within the United Nations Framework Convention on Climate Change process and "an opportunity to bring migration into the discussion and to feed into national plans." ${ }^{, 67}$

62 See e.g., Jane McAdam, "Historical Cross-Border Relocations in the Pacific: Lessons for Planned Relocations in the Context of Climate Change" (2014) 49 Journal of Pacific History 301.

63 Cook Islands in Nansen Initiative, supra note 49; Protection Agenda, supra note 1 at para 94.

64 Sendai Framework, supra note 43.

65 "Adoption of the Paris Agreement," Decision 1/CP.21, UN Doc FCCC/CP/2015/10/Add.1 (29 January 2016).

66 Ibid at para 49; see also para 50. The preamble also notes that when taking action to address climate change, states parties should "respect, promote and consider their respective obligations on human rights, the right to health, the rights of indigenous peoples, local communities, migrants, children, persons with disabilities and people in vulnerable situations and the right to development, as well as gender equality, empowerment of women and intergenerational equity."

67 Walter Kälin \& Kelly Clements, “Co-Chairs' Summary: Thematic Session 2: Addressing 'New' Root Causes: Urbanization, Food Insecurity, Water Scarcity, Natural Hazards and Climate Change," High Commissioner's Dialogue on Protection Challenges: Understanding and Addressing Root Causes of Displacement (16-17 December 2015) at 3, $<$ http://www.unhcr.org/56e6de4f9.html>. United Nations Framework Convention on Climate Change, 9 May1992, 1771 UNTS 107 [emphasis omitted]. 
We need a holistic, cross-cutting, and coordinated approach across government, and across international organizations, so that the connections between different policy areas are recognized and the gaps addressed. Strategies such as disaster risk reduction and climate change adaptation can help to mitigate against displacement if disaster strikes. Temporary, planned evacuation can provide a pathway to safety and emergency support. Long-term, sustainable development projects can enhance community resilience over time, creating new labour opportunities and technologies, and building capacity for selfhelp. More predictable humanitarian and temporary stay arrangements can assist those displaced across a border. Creating opportunities for migration away from at-risk areas can open up new livelihoods, skills, knowledge, and remittances while simultaneously relieving demographic and resource pressures. Planned relocation can move people out of harm's way, but it must be undertaken with extreme care and sensitivity. What governments do (or fail to do) today will shape whether we see future humanitarian catastrophes or systematic, well-attuned responses. Understandably, many people may wish to avoid having to move altogether, but a pre-planned mobility strategy will be far preferable to displacement in the face of pending disaster. 